\title{
UNSUPERVISED USE OF GADGETS AS A CAUSE OF CYBERBULLYING AMONG PRIMARY SCHOOLCHILDREN
}

\author{
TETYANA BLYZNYUK
}

\begin{abstract}
The article substantiates the relevance of the problem and the consequences of the popularity of modern gadgets (smartphones, laptops, smart TVs, game consoles, health trackers, smart watches, webcams, iPads and tablets, earphones) among primary school students during and beyond the educational process. The author lists the advantages of using innovative digital technologies in the classroom for both the student and the teacher: considerable interest and motivation for learning activities, better opportunities for implementation of the individual learning principle, formation and improvement of necessary life skills and competences, etc. The author presents the results of a survey conducted with HEI academic staff regarding their attitude to the problem and their awareness of the most effective gadgets for the enhancement of educational process. The study also proves the failings of the uncontrolled use of modern technologies among younger students, which has apparently become one of the major reasons for the spread of cyberbullying and aggression in the school environment. The purpose of this paper is to draw attention to this issue and to suggest some ways of addressing it in four stages: family and friends, school, local community and regional-national level, characterized by specific procedures and actions. Among the results of the study, there is an increase in the number of scientific publications, both domestic and foreign, which shows the considerable interest among scientists and the urgent need in the context of searching ways of preventing and combatting cyberbullying among primary school students.
\end{abstract}

Keywords: cyberbullying, gadgets and electronic devices, primary school students, advantages and disadvantages of using technology, school environment.

\section{INTRODUCTION}

Gadgets have become an integral part of our lives, no matter, be it a smart phone, laptop, iPod or iPad. Today, humanity is on the edge of another technological revolution where the generation of digital children - Alpha generation who emerged after 2010, has to cope with it. Today's children have access to far more information than all previous generations at their age had before. In other world countries and in Ukraine in particular, there are growing pragmatists who want to express themselves or even earn from the youngest age on their own hobbies, interests, everyday achievements and more. Their main idea is freedom and self-expression where gadgets are not simple entertainment but a means to get the goal. While for some schoolers that actually means that they are learning computer languages, creating websites or contents, and even building robots, most others simply use today's 
technology to watch videos on YouTube, play games or just chat on their cell phones and send text messages.

Children get addicted very quickly and easily to various gadgets and engaged with social media. They are so used to electronic devices that when we observe kids somewhere, like the dentist's office, bus station, cafe or airport, they all are on them. To tell the truth, if we analyze ourselves, adults (educators, psychologists, celebrities, politicians, etc.), so are we...showing our children not the best example. Parents and teachers do tell children ( 6 and 11 years) not to use tablets or smartphones too much but often we just cannot tell them to stop doing it, it is often beyond our control. The children of the generation Alpha do not remember the world without gadgets - smartphones, tablets, e-readers and laptops.

The problem of advantages and disadvantaged of ICT in the process of operating general secondary education institutions is highlighted in scientific and advisory works of such contemporary domestic scientists as: T. Blyznyuk, O. Budnyk, M. Gladun, O. Fedorenko, V. Kalinin, V. Kovalenko, Ju. Matvienko, N. Morze, L. Naidionova, Y. Nosenko, O. Ovarchuk, S. Vasylenko, A. Volosiuk, I. Vorotnykova, A. Yatsyshyn and others.

\section{RESULTS AND DisCUSSION}

Gadgets really prove to be extremely useful at times. In an increasingly digital world, technology serves as an incredibly powerful tool to educate and shape young minds. For some of us, this generation of digital natives in using technology in collaborative and social ways that will revolutionize learning and increase efficiency of education process. Among numerous educational advantages of gadgets for primary school students include the ability to take notes quickly and efficiently to store information, the opportunity to collaborate with others peers using numerous Apps or similar platforms, access interesting and useful educational information available online and use visualization like concept mapping or mind mapping software. Moreover, gadgets sometimes is the only access to education for people in remote areas or those with special educational needs and disabilities. There are many benefits for teachers in implementing gadgets usage at the lessons as well. Firstly, nowadays teachers can find a wide variety of highly developed electronic education resources, which are able to bring fresh view to improve teaching. Secondly, they enhance the traditional ways of teaching and to keep students more engaged in learning. Thirdly, educators update the process of formative assessment by using trusted tools and enhance collaboration activities in the classroom, and knowledge sharing between teachers aimed at experience and best teaching practices exchange. Finally, the popularity and confident use of electronic devices have become even more apparent since the time when Ukraine introduced national quarantine due to the spread of coronavirus in the world. In order not to create a big gap in students' knowledge that teachers use numerous on line learning platforms and tools to keep them busy during those tough times of the pandemic.

Students can learn useful life skills and competences through technology. By using technology in the classroom, for instance, both teachers and students can develop skills crucial for the 21st century representative. Students can gain the skills they will need to be successful, and, what is more important, competitive in the future. Modern learning is about collaborating, solving complex problems, critical thinking development, improving communication and leadership skills, and increasing motivation, adaptation and productivity. What is more, gadgets can help develop many practical skills, necessary for everyday life, including creating presentations, learning to trust sources on the Internet, maintaining proper online respect behaviour, and writing emails.

Taking into account different points of view that exist today among educators of different levels from the preschool to the higher education institution, we decided to learn the current situation of using electronic devices in education at Ukrainian schools and carried out a survey among the PNU academic staff who train future pedagogues for New Ukrainian School. (See Figure 1). 


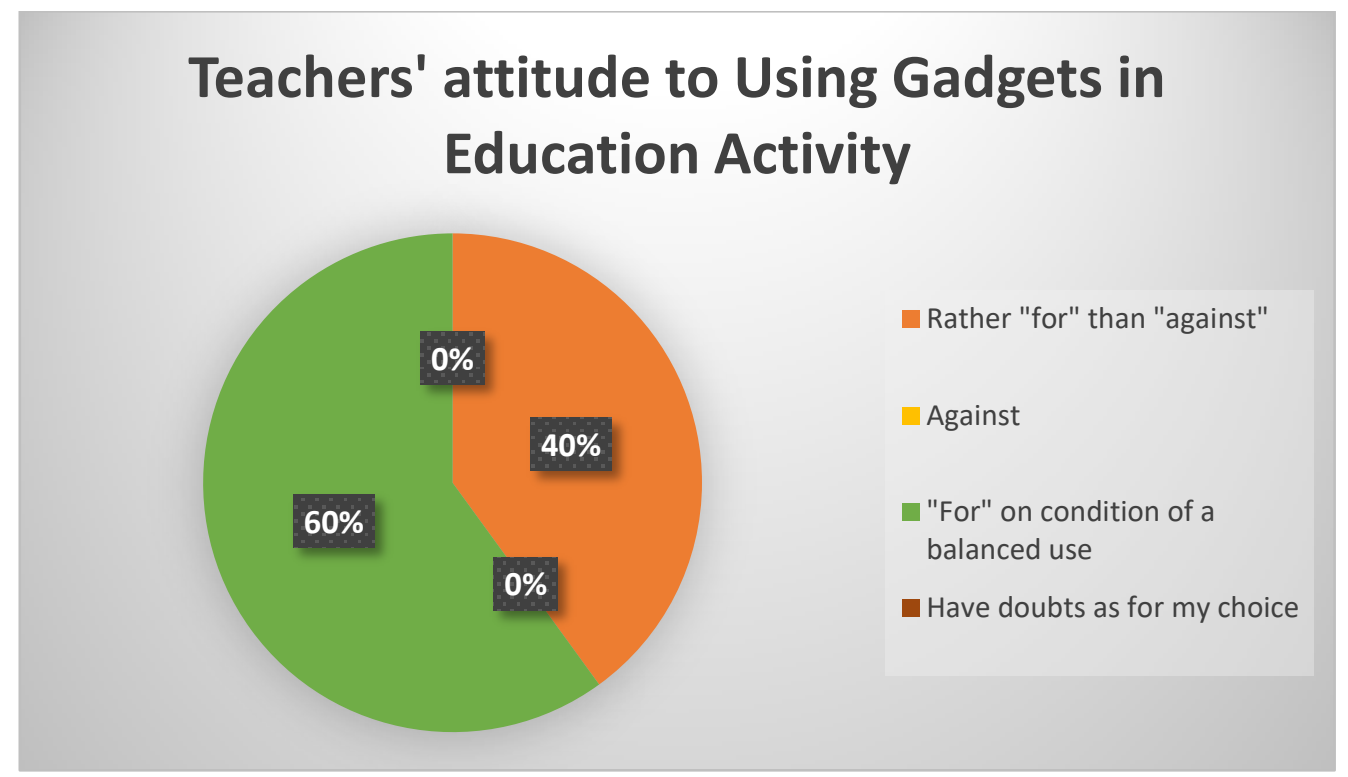

Fig. 1. Teacher's attitude to using gadgets in education activity

According to the results, $100 \%$ of respondents support the idea of using innovative technologies, namely electronic devices in education activity, however their opinions separated the greater part of them approve of using gadgets only if it is balanced with other education activities. (15 out of 25 educators). The other respondents consider they are rather "for" than "against" and believe that the use of ICT in teaching will increase the efficiency of the education process. There appeared none of the respondents who was totally against or hesitated on the issue of using gadgets in education activities.

The results of teachers' responses to the question "What gadgets do you consider the most efficient in teaching" are given in Figure 2. Most of the respondents find a tablet the most appropriate for education purposes, and then go smartphones, laptops, smart boards, games consoles, cameras, iPads, headsets and headphones, TVs, and even flash cards. Now the question of our further survey will be how well the teachers are familiar with the possibilities of various electronic devices in teaching/learning process.

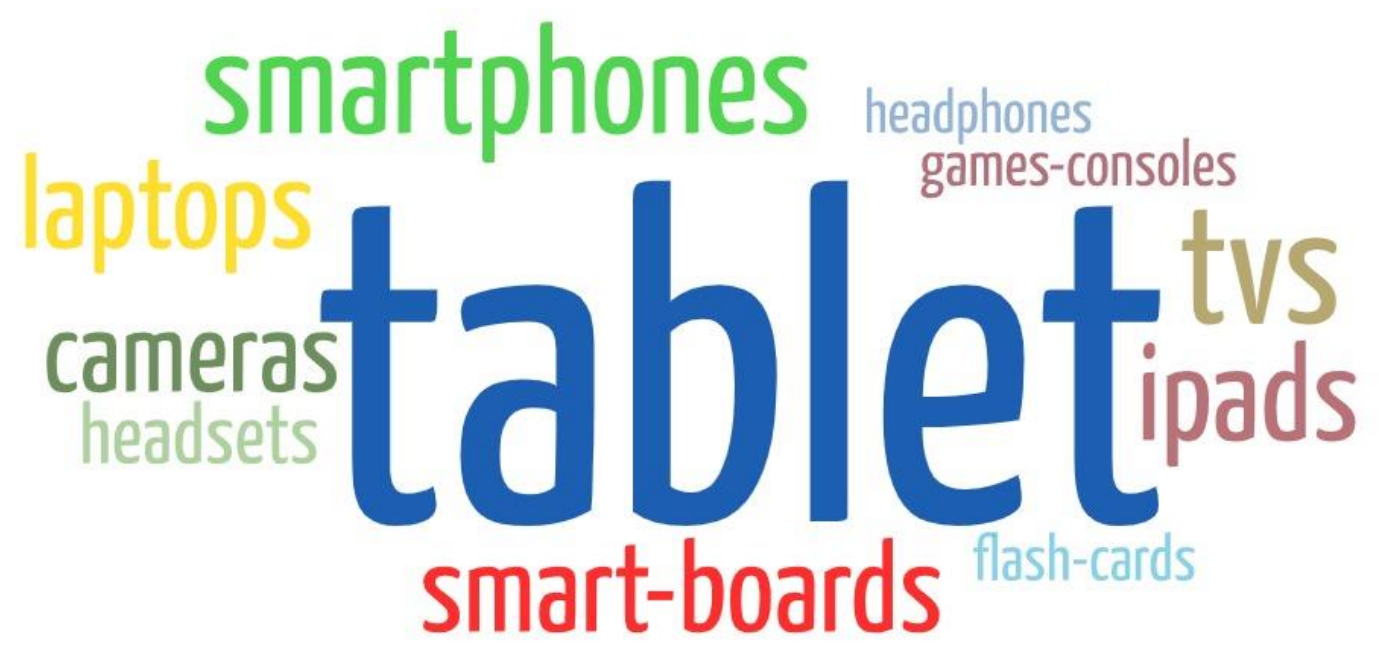

Fig. 2. Gadgets efficient in education activities

Multitasking is another hallmark of the Alpha generation. Digital children will not be able to survive without this quality in the world of the future, where they will have to compete with developed artificial intelligence, and even live in a changing and poorly predicted time. The representatives of 
Alpha generation actively fight for environmental protection, and have an active civic position. Greta Thunberg, the teenage climate change activist, is a perfect example what children can do with the help of gadgets. In the future children can do even much more with technology than inspire millions of young people around the world to go to the streets of the global cities and demand action on climate change.

On the other hand, it is obvious that younger children's ownership and access to technologies is increasing, and as such, they are exposed not only to the undeniable benefits but also to abundant risks associated with their use. Primary schoolchildren and youth use 4-5 times more of the recommended amount of technology and social media, which often has very serious and life threatening consequences (Kaiser Foundation 2010, Active Healthy Kids Canada 2012). Unfortunately, many of the things kids do online and with their gadgets can lead to a lot of trouble if they are not monitored or supervised. New technologies often arise new problems. Handheld devices (cell phones, tablets, electronic game consoles) modern media technologies have dramatically increased the accessibility to different kinds of information, causing unsupervised pastime of children. In our research, we do not intend to stop or substantiate numerous physical health problems it may cause. However, we should attempt to draw adults' attention to the problem that violent media content is the reason for children's aggression and offer some ways of how to reduce or partially solve the issue.

Many researchers assume that "the average age of the aggressor is usually similar to that of the victim (Ballesteros, 2017), a period of transition from childhood to adolescence. Added to this is that the star gift in the first communion of children is a smartphone, being an aggravating factor in these cases, since the computer and mobile phone are the channels through which such actions are perpetrated" [2, p. 116]. Today, the question of fostering tolerance of primary school students in the educational process of the modern Ukrainian school is extremely urgent. Among the key factors behind it are increase in aggression, intolerance in society, the phenomenon of bullying, outsourcing and harassment in teams among children; implementation of inclusive education. Educating tolerance in children is a challenge for parents, preschool teachers, and other educators. Particularly relevant is the search for new methods and approaches that would be helpful in the process of fostering tolerance in junior students.

The extensive use of smartphones and the Internet have even lead to new ways for kids to be bullied-cyberbullying. The OECD research [Organisation for Economic Co-operation and Development. The Protection of Children Online: Recommendations of the OECD Council: Report on Risks Faced by Children Online and Policies to Protect Them; OECD: Paris, France, 2012.] found that in Europe, up to 31 per cent of children aged 6-14 years had encountered cyberbullying as measured across various periods, which was dependent on the scale incorporated in the studies. Such researches demonstrate a need to investigate cyberbullying issues with young children. It is an international issue for schools, young people and their families.

The problem of cyberbullying is mostly studied by researchers dealing with teenagers (M. Anderson, Ju. Barlińska, A. Szuster, M. Winiewski, A. Denise E.; M. Rathe, C. Jacobson, A. Bailin, R. Milanaik, A. Adesman, J.W. Patchin, S. Hinduja and others). The issue is also highlighted by Ukrainian researchers: $S$ Kutsenko tried ti find the ways of how to protect schoolchildren from cyberbullying; L. Naidionova stressed the cyberbullying is a new problem of Internet [9]; O. Mikheeva, M. Kornienko studied the problem in the social and pedagogical context [8]; K. Dzufer considered cyberbullying as a threat of the XXI century and understood it as a relatively new kind of persecution children that occurs through virtual communications.. Since, there is limited research dedicated to the problem of cyberbullying among the younger age groups, primary schoolchildren. This is particularly relevant as these kids are now accessing more devices, earlier and more frequently.

We consider it important to realize the concept of "cyberbullying" in theory of modern scientific researches: to highlight the multidimensionality of its phenomenon. Analyzing the issue, we found out that foreign and domestic scientists have different approaches to its interpretation. Thus, P. Smith treats cyberbullying as aggressive, deliberate actions taken by a group or an individual using electronic forms of communication against a victim who cannot protect oneself $[3,13]$. Another researcher S. Monks 
believes that cyberbullying is a violent, threatening act by one child to another by electronic means of communication, such as cell phones, websites, social networking, online groups and others [7].

After generalizing different approaches of scientists in this context, we have concluded that cyberbullying or Internet mobbing is a modern form of aggression that has become widespread with the popularity of gadgets, mostly mobile phones, and the Internet. All its forms intend to provoke, harm, or humiliate a child remotely, normally without physical violence (as opposed to bulling), decrease one's self-esteem. Social networks, chats, smartphones and more are the "weapons" of the buller $[2 ; 4 ; 5 ; 12 ; 14]$.

Contemporary cyberspace has some unpleasant features: the buller is anonymous and can hide behind false identities. Such uncertainty heightens the child's anxiety, the victim may begin to visualize of the power and strength of the aggressor and in this regard - about one's own defenselessness and vulnerability, relying on (perhaps) personal past life experiences. The buller often refers to wide audience, and innumerable invisible witnesses. Besides, the aggressor has a constant, unlimited by time and place, access to the victim through electronic devices. Continuity and no feedback in cyberbullying can be especially dangerous for children and adolescents, having or experiencing traumatic experiences, isolation and misunderstanding within the family or friends.

Kids have always had their virtual imaginary worlds, their games and their secrets from adults. The mystery of the modern generation is predictable and, for the most part, not obvious to adults. Younger children require different methods of engagement. As educators, we need to be specifically aware of cyberbullying. Therefore, primary school teachers should be trained to identify the child that may suffer from cyberbullying, deal with the problem, but what is more significant, foresee it by creating favorable friendly classroom environment.

The American scientist D. Nolte emphasized the importance of creating a caring pedagogical climate in which there would be no chaos and oppression, and on the contrary, the conditions for successful development of important personality traits would be created. At the same time, according to the scientist, it is necessary to be guided by certain rules of education, to observe pedagogical commandments, formulated in a kind of code "Children learn how to live" accordingly:

- if children are surrounded by constant criticism, they learn to condemn.

- if children live in hostility, they learn from violence.

- if children live in tolerance, they learn tolerance.

- if children are supported, they learn to be confident.

- if children live in fairness, they learn to be fair.

- if children live in safety, they learn to trust.

- if children are treated with approval, they learn and raise self-esteem.

- if children live recognized, they learn friendship. They learn to find love on Earth" [11].

We attempt to suggest dealing with cyberbullying on four levels: family and friends, school, local community and regional-national. Each of them is characterized by specific procedures and actions.

Throwing the light on the family or/and friends level, we must admit it is one of the highest importance as no one knows the child better than dear close people. Together family can consider what to do to cope with the problem and at the very least give a child emotional support during this difficult time. However, relatives apt to underestimate their role here and mostly delegate personal responsibility on somebody else, schoolteachers, for instance.

Definitely, there are many things schools can do to address the issue of cyberbullying at their level. Firstly, to promote a culture of mutual respect and tolerance or appreciation for diversity. We find it urgent to note that the problem of fostering tolerant behaviuor is the deliberate creation of conditions that require interaction with and respect for others. After all, the purpose of fostering tolerance in the context of preventing cyberbullying in modern school is to educate young people's needs and readiness for constructive interaction with different people, regardless of their national, social identity, way of thinking, appearance, behavior, worldview and other views, etc.

We can do a few more things as educators to prevent curtail cyberbullying in schools. 
Bring up Digitally Competent Citizens. Cyberbullying has no gender, it - is impersonal in nature. It is urgent to explain children that there are rules, which should be applied both inside and outside the digital setting. Teachers have to inform young students how to be cyber safe. To our mind, the best idea is not moralizing and prohibiting but inviting an expert who might clearly provide some tips and even disseminate free handouts to teach students how to be safe online. By incorporating technology in the classroom, teachers can focus on the ethical use of technology. Prohibiting technology often makes the problem even worse. Teaching students how to use technology appropriately is better than having unsupervised. Microsoft representatives in Ukrainian cities and towns can be invited to the classroom for a meeting and provide a free instructional program to teach digital citizenship and ethical use of technology.

Promote Understanding and Awareness. Knowledge is power. It changes social perceptions. Instead of creating panic over technology use or spread misunderstandings between adults (parents and teachers) and schoolers, awareness gives way to a positive atmosphere and friendly relations. Educators should speak about cyberbullying in their classrooms, see what kids know about it, how they treat it, etc. It is a good idea to teach students about physical, psychological and legal consequences. Researchers, inservice teachers, student-teachers should explore the problems like technology risks, cyber safety and positive online communities; talk about possible cases of cyberbullying and their resolution. A perfect way to highlight the benefits of technologies is to emphasize how children can use it for creating a managed space for classmates to compliment each other on school achievements or work together on a class project.

Openness to Speak About Aggression. Children must trust the teachers and have to realize that they should expose online aggression. Most kids feel fear, shame before peers or anxiety to be punished by parents and lose freedom in using gadgets. Thus, they prefer to not inform of the problem and often believe that adults have no ideas to resolve the situation. It is important for educators/parents to break the silence surrounding cyberbullying. In our opinion, we should let children know that we do not blame technology for the problem, but irresponsible use of it. Help kids trust us. They need to know whom and where they can go to before a problem occurs. An anonymous box (a secret box) in the classroom to report cases can be a good example, so that children know they can feel safe to report information anonymously. It may also prevent aggressors from engaging in bad behavior. Research suggests that a parenting style that is emotionally warm with clear limits best creates resiliency in regards to digital aggression. Teachers can follow the same example: be clear, empathetic, and communicate openly with students.

Miriam Clifford, a freelance education writer holds a Bachelor in Science from Cornell University and a Masters in Teaching with Honors from City University of Seattle, recommends using a 5-R method (the 5 R's) when addressing cyberbullying situations. That is Respond always, Research facts of the situation, Record documentation, Report findings, and Revisit the issue to make sure it is resolved.

Another advice to create solid relations in the classroom is practicing Team Building Activities or Collaborative Work. Collaboration is a powerful way to get children to behave cohesively. The purpose of such activities is to make all classmates work together towards a common goal. They had to use all of their individual strengths and realize each person's abilities were necessary to complete the task. Teachers might consider having a weekly, monthly class projects or similar activities; organize events that might involve primary school students to socialize with others who they are not normally engage with.

Pedagogy of Partnership against Cyberbullying. It is relevant to promote education for teachers, administrators, and parents. Cyberbullying problems frequently change due to the changing nature of technology. It is important to stay up to date. Universities or other non-profit organizations arrange seminars, webinars, round tables and workshops aimed to educate teachers and parents; provide free multimedia training resources specializing in this field. Parents may often be unaware of cyberbullying, as they did not experience such an issue during their school years. It just did not occur! That is why it is important to report what is happening so that they can intervene at home. Educators might suggest parents buy filtering software or special phones for younger children. 
Cyberbullying must be taken seriously. Authorities on local community and regional-national levels might suggest appropriate programs on monthly basis or organize annual events. A good move in this context is the event held every year on the second Tuesday of February when people celebrate World Internet Security Day. The activities of this day are aimed at spreading knowledge about the safe and responsible use of the latest information and communication technologies. Thus, February 11, 2020, many world countries marked the World Safer Internet Day with the slogan "Together for the Best of the Internet". This day intended to engage everyone who participates in creating a better Internet for all, including the youngest users. Moreover, many people of different ages and profession take part in online communication for the sake of providing the best digital experiences. Ukraine, of course, has become an active member of such an event and taken an advantage of this unique opportunity for online security activities with the world. For instance, students and academic staff of the Precarpathian National University joined the widespread action towards safety on the Internet.

Since January 2019, the law against bullying came into force in Ukraine. Accordingly, any psychological, physical, economic or sexual abuse, including the use of electronic communications, is punishable by penalties. Primary school children should also be acquainted with the basics of law restrictions in this context and understand the consequences of their misbehaviour. Teachers should make students realize since the early age that bullying of any kind, including cyberbullying is unacceptable. There are many ways how to teach students about being responsible citizens who are accept individual differences. Observing and caring teacher makes sure that groupings in the classroom allow students to work with different people thus they try to create activities to build on strengths, to show students how each person has something unique to contribute to. Responsible technology use teaches tolerance and respect for diversity. Finally, it is important for educators to remember our duty is to protect students' human rights.

\section{CONCLUSIONS}

After the research conducted, we conclude frequency of online activities put primary school children in high risk of developing pathological Internet use. Our findings indicate that Internet activities with the help of gadgets are becoming more popular among younger schoolers, changing the age profile of Internet users. The role of family and friends, school and community is becoming extremely important in preventing the potential threats by providing guidance on how to use Internet safely and forming digitally competent citizens, but also in detecting pathological behaviors at early stages. School-based engagement in Internet use for both screening and surveillance might be a part of a multifaceted strategy for reducing child pathological Internet use. The current study provides important information that could be useful in formulating age-specific health policies in Internet safety. Finally, it provides evidence that the need for training for safe gadget use should start at the very first stages of school life, since this is when both Internet usage and the exposure to Internet risks begin. Going through a cyberbullying incident is very difficult.

\section{REFERENCES}

[1] Blyznyuk T. Educational innovations and technological advancement in English language teaching: training teachers for NUS. Educational Horizons [Osvitni obrii]: scientific-pedagogical journal, 2 (49) (2019), 93-96. doi: https: 10.15330/obrii.49.2.93-96

[2] Caceres-Reche M.P., Hinojo-Lucena F.J., Navas-Parejo M.R., Romero-Rodrigues J.M. The phenomenon of cyberbullying in the children and adolescents population: a scientometric analysis. Research in Social Sciences and Technology, 4 (2) (2019), 115-128. Available at: https://ressat.org/index.php/ressat/article/view/406 
[3] Smith P., Mahdavi J., Carvalho M., Fisher S., Russell S., Tippett N. Cyberbullying: its nature and impactions condary school pupils. Journal of Child Psychology and Psychiatry, 49 (2008), 376-385. doi: 10.1111/j.1469-7610.2007.01846.x

[4] Katz I., Lemish D., Cohen R., Arden A. When parents are inconsistent: Parenting style and adolescents' involvement in cyberbullying. Journal of Adolescence, 74 (2019), 1-12. doi: 10.1016/j.adolescence.2019.04.006

[5] López-Pradas I., Romera E.M., Casas J.A., Ortega-Ruiz R. Cyber gossip and cyberbullying during primary school years. Psicología Educativa, 23 (2017), 73-80. doi: 10.1016/j.pse.2017.05.007

[6] Livingstone S., Smith P. Annual research review: Harms experienced by child users of online and mobile technologies: the nature, prevalence and management of sexual and aggressive risks in the digital age. J. Child Psychol. Psychiatry, 55 (6) 2014, 635-654. doi: 10.1111/jcpp.12197

[7] Monks C., Robinson S., Worlidge P. The emergence of cyberbullying: a survey of primary school pupils' perceptions and experiences. Sch. Psychol. Int., 33 (5) (2012), 477-491. doi: 10.1177/0143034312445242

[8] Mikheeva O., Kornienko M. Cyberbullying as a social and pedagogical problem. Young Scientist, 11 (63) (2018), 247-251. (in Ukrainian)

[9] Naidionova L. Cyberbullying or aggression on the Internet: attempts of nderstanding and child's protection. In: Naidionova L. Methodical recommendations, 4. Kiev, 2011. (in Ukrainian)

[10] Naidionova L. Mediapsychology: the basics of the reflexive approach: a textbook. National Academy of Pedagogical Sciences of Ukraine, Institute of Social and Political Psychology. Imeks-LTD, Kirovograd, 2013. (in Ukrainian)

[11] Nolte D. Community of caring. Program guide. Walker Publishing Company, New York, 1995.

[12] Olweus D. Bullying at School. In: Huesmann L.R. (Ed.) Aggressive Behavior. The Plenum Series in Social/Clinical Psychology. Springer, Boston, MA, 1994, 97-130. doi: 10.1007/978-1-4757-9116-7_5

[13] Smith P. Understanding School Bullying: its Nature and Prevention Strategies. SAGE Publications Ltd, London, UK, 2014. doi: 10.4135/9781473906853

[14] Wachs S., Bilz L., Niproschke S., Schubarth W. Bullying intervention in schools: A multilevel analysis of teachers' success in handling bullying from the students' perspective. Journal of Early Adolescence, 39 (5) (2019), 642-668. doi: 10.1177/0272431618780423

Address: Tetyana Blyznyuk, Vasyl Stefanyk Precarpathian National University, 57, Shevchenko Str., IvanoFrankivsk, 76018, Ukraine.

E-mail: tetyana.blyznyuk@pnu.edu.ua

Received: 17.01.2020; revised: 25.03.2020.

Тетяна Близнюк. Некероване використання гаджетів як причина кібербулінгу серед учнів початкової школи. Журнал Прикарпатського університету імені Василя Стефаника, 7 (1) (2020), 48-56.

У статті обгрунтовано актуальність проблеми та наслідки популярності сучасних гаджетів (смартфонів, ноутбуків, смарт-телевізорів, ігрових приставок, трекерів здоров'я, смарт-годинників, вебкамер, айпедів та планшетів) серед учнів початкової школи під час освітнього процесу та за його межами. Автор перелічує переваги використання індивідуалізації цифрових технологій у класі як для учня, так і для вчителя: значний інтерес та мотивація до навчальної діяльності, кращі можливості для імплементації принципу навчання, формування й удосконалення необхідних життєвих навичок і компетентностей тощо. Авторкою представлено результати проведеного опитування викладачів закладів вищої освіти на предмет їхнього ставлення до цієї проблеми та обізнаності щодо найефективніших гаджетів у освітньому процесі. У дослідженні також обгрунтовані недодіки 
некерованого використання сучасних технлогій серед молодших школярів, що стало однією 3 вагомих причин поширення кібербулінгу та агресивного поводження у шкільному середовищі. Мета статті привернути увагу до цього питання та запропонувати деякі шляхи його вирішення на чотирьох етапах: сім'ї та друзів, школи, місцевої громади та регіонально-національного рівня, які характеризуються конкретними процедурами та діями. Наголошено на збільшенні кількості наукових публікацій як вітчизняних, так і зарубіжних, що є свідченням його зацікавлення серед науковців і нагальну потребу у пошуку шляхів запобігання кібербулінгу серед учнів початкової школи.

Ключові слова: кібер-залякування, гаджети та електронні пристрої, учні початкових класів, переваги та недоліки використання технології, шкільне середовище.

\section{ITำPED}

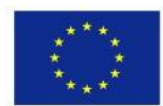

Co-funded by the

Erasmus+ Programme

of the European Union

"The article has been prepared in the framework of the Erasmus+ project "MoPED - Modernization of Pedagogical Higher Education by Innovative Teaching Instruments", No. 586098-EPP-1-2017-1-UAEPPKA2-CBHE-JP. This project has been funded with support from the European Commission. This publication reflects the views only of the author, and the Commission cannot be held responsible for any use which may be made of the information contained therein". 